\title{
Education, Vulnerability, and Resilience after a Natural Disaster
}

\author{
$\underline{\text { Elizabeth Frankenberg }}^{1}$, Bondan Sikoki $^{2}, \underline{\text { Cecep Sumantri }}^{2}$, Wayan Suriastini $^{2}$ and $^{\text {Duncan Thomas }}{ }^{1}$
}

\begin{abstract}
The extent to which education provides protection in the face of a large-scale natural disaster is investigated. Using longitudinal population-representative survey data collected in two provinces on the island of Sumatra, Indonesia, before and after the 2004 Indian Ocean tsunami, we examine changes in a broad array of indicators of well-being of adults. Focusing on adults who were living, before the tsunami, in areas that were subsequently severely damaged by the tsunami, better educated males were more likely to survive the tsunami, but education is not predictive of survival among females. Education is not associated with levels of post-traumatic stress among survivors 1 year after the tsunami, or with the likelihood of being displaced. Where education does appear to play a role is with respect to coping with the disaster over the longer term. The better educated were far less likely than others to live in a camp or other temporary housing, moving, instead, to private homes, staying with family or friends, or renting a new home. The better educated were more able to minimize dips in spending levels following the tsunami, relative to the cuts made by those with little education. Five years after the tsunami, the better educated were in better psycho-social health than those with less education. In sum, education is associated with higher levels of resilience over the longer term.
\end{abstract}

Key Words: development; disaster; education; resilience; vulnerability

\section{INTRODUCTION}

Disasters are threats to population well-being that derail socioeconomic progress, strain social safety nets, and require complex assistance and recovery interventions. Over the last decade alone, Indonesia, Sri Lanka, Pakistan, China, Haiti, and Japan have all experienced natural disasters with death tolls in the tens of thousands. The high mortality disasters in recent years, combined with predictions that these events will increase in frequency as a result of global warming and rising population densities in coastal areas, have increased interest in more fully understanding the factors that underlie trajectories of disaster recovery over the longer term.

Several challenges impede building this deeper understanding of disaster recovery from the existing research literature. These include the difficulty of studying events of catastrophic magnitude, the limited size and representativeness of the samples and follow-up periods of available data, and consequently the relative lack of empirical studies focusing on longer-term outcomes for large representative populations (National Research Council (NRC) 2006, Galea and Maxwell 2009, Sastry and Vanlandingham 2009). One emerging theoretical insight is the conceptualization of disaster impact and recovery in terms of vulnerability and resilience, with the attendant recognition that each is embedded in a context of social processes that may, themselves, contribute to preexisting variation in inequality in multiple dimensions in a society (NRC 2006, Tierney 2007). This theoretical perspective complements needs on the empirical side to identify the population sub-groups who suffer the most devastating and longest-lasting impacts of disaster. These challenges are recognized as critical for both science and for policy (Linnerooth-Bayer et al. 2005, Telford and Cosgrave 2007, Buttenheim 2010, Horton 2011, Padgett and Warnecke 2011).

This study uses population-representative longitudinal survey data collected before and after the 2004 Indian Ocean tsunami to consider the specific question of whether education moderates the immediate and longer-term impacts of a catastrophic natural disaster. Addressing this question with data from a catastrophic disaster collected over a 5-year time frame speaks to the broader theoretical line of inquiry regarding the influence of socioeconomic status on "vulnerability" and longer-term "resilience" in the aftermath of a major disaster.

It is important to note that, in general, the better educated tend to earn more, have greater wealth, and live longer and healthier lives (Lutz and Samir 2011). They also tend to live in areas that are less prone to natural disasters and to be better protected against shocks either through some form of formal or informal insurance or through greater diversification of their livelihoods as well as their financial assets and social support (Strauss and Thomas 2008). As a result of these choices, it is difficult to disentangle whether the better educated are better able to recover over the longer term from a disaster that has equal immediate impacts regardless of education level, or whether the better educated suffer fewer immediate impacts at the outset because of prior investments in risk mitigation and insurance.

The Indian Ocean tsunami, in combination with the data we analyze, provides a window into this issue for several key reasons. First, it is reasonable to treat the tsunami as 
completely unanticipated, at least along the coast of the island of Sumatra. Second, in the communities that bore the most intense force of the waves, the tsunami had a devastating impact on livelihoods. Third, we draw on an unusual data set that provides information on multiple dimensions of impact and recovery for a population-representative sample first interviewed 10 months before the tsunami and then for 5 years after the event.

The destruction wreaked by the tsunami was massive and far reaching. Importantly for this research, we show that in severely damaged areas, the immediate impacts were broadly the same for people across the entire distribution of education. In contrast with many natural disasters, education conferred little protection from the tsunami's short-term effects. However, over the longer term, our analysis indicates that the better educated are substantially more resilient with respect to psychosocial health and economic status.

We conclude that the better educated are better placed to mitigate the deleterious consequences and to embrace new opportunities in the aftermath of even a major large-scale and unanticipated disaster. It is not possible to ascribe a causal interpretation to this evidence. Those who have invested more in education may be more entrepreneurial, nimble, and better equipped to take on new opportunities and challenges after a major disaster. The greater resilience of the better educated may also arise because of better access to financial resources or greater availability of social resources after the tsunami.

\section{THE DISASTER}

At 7:58 a.m. on 26 December 2004, an earthquake measuring an estimated 9.3 on the Richter scale occurred off the coast of Sumatra, Indonesia. Faulting from the earthquake lasted 8 minutes, temporarily disrupting the earth's rotation and generating a 1,200-km rupture along the floor of the Indian Ocean (Bunting et al. 2007). The vertical displacement from the quake was $5-15 \mathrm{~m}$, which generated huge tsunami surges that ultimately reached the shores of all countries that rim the Indian Ocean (Kerr 2005, Lay et al. 2005, Marris 2005, Sinadinovski 2006).

The first of the waves slammed into the island of Sumatra within 15 minutes of the earthquake. In Aceh, the Indonesian province closest to the rupture, the tsunami engulfed communities along $800 \mathrm{~km}$ of coastline. Studies estimate that the tsunami killed 130,000 individuals, with another 30,000 classified as missing (Rofi et al. 2006, Doocy et al. 2007). Some 700,000 individuals were displaced, and damage to property and infrastructure was valued at 4.5 billion (The Consultative Group on Indonesia 2005).

In areas severely damaged by the tsunami, the water swept away everything in its path including roads, bridges, and buildings. At the beachfront in Banda Aceh, water depths were approximately $9 \mathrm{~m}$ and even further inland reached the height of two-storey buildings. Along parts of the west coast of Aceh, the water removed bark from trees as high as $13 \mathrm{~m}$ (Borrero 2005). Where rivers emptied into the ocean, the water moved inland as much as 6-9 km, flooding plains and arable land. In other areas, the water reached about 3-4 km inland (Kohl et al. 2005, Umitsu et al. 2007).

From the perspective of contrasting the impact of this catastrophic disaster on the better educated relative to those with less education, two important features of the Indian Ocean tsunami distinguish it from other natural and manmade disasters. First, the tsunami was completely unexpected. The last major tsunami on the coast of mainland Aceh took place over 600 years ago (Monecke et al. 2008). Waves reached some parts of coastal Aceh within minutes of the earthquake, and retreating water, a signature of an impending tsunami, was not interpreted as a sign of danger by the vast majority of the population. Only residents of Simeulue island, where a smaller tsunami occurred in 1907, systematically relocated to higher ground, and, correspondingly, the survival rate in Simeulue was very high (Gaillard et al.,2008). The unexpectedness of the tsunami contrasts sharply with disasters for which there is some advance warning, such as hurricanes, tornadoes, and floods. Warnings before Hurricane Katrina, for example, enabled people with more resources-which the better educated often have-to protect themselves and their livelihoods at least partially from the disaster.

The second important feature of the tsunami for this research is that the force with which the tsunami waves hit the shore varied locally as a function of geophysical factors. The height and inland reach of water from the tsunami were a complicated function of both the vertical displacement of the seafloor (which varied along the rupture) and features of coastal topography, such as the slope of the coastal zone, elevation of the beachfront, and the direction of the wave relative to the land (Ramakrishnan et al. 2005). Accordingly, a component of the intensity of the tsunami's impact is random and is unrelated to the education of those living in the area. It is, therefore, reasonable to treat the tsunami as a large and unanticipated natural disaster that is unlikely a priori to have spared the better educated.

\section{DATA AND MEASUREMENT}

Research on the impact of disasters has been limited by a dearth of population-representative data that follow samples of sufficient size before and after the disaster. Constructing population-representative samples after an event that displaces a large fraction of the population is extremely difficult, and few studies have access to information on populations before a major disaster strikes. The studies that do are rarely well positioned to locate and interview the individuals who move from place to place in the disaster's aftermath (Buttenheim 2010, Gray et al. 2011, Horton 2011). 


\section{Data}

We draw on longitudinal data that we designed and collected as part of the Study of the Tsunami Aftermath and Recovery (STAR). The study covers individuals who were living in coastal areas of the Indonesian provinces of Aceh and North Sumatra before the tsunami. Building on the foundation provided by a pre-earthquake baseline survey that interviewed nearly 27,000 individuals, we conducted follow-up surveys annually for 5 years after the disaster.

The baseline survey participants were part of a socioeconomic survey, SUSENAS, conducted by Statistics Indonesia in February 2004, 10 months before the Sumatran-Andaman earthquake. Statistics Indonesia has conducted the SUSENAS annually throughout Indonesia since 1963. The survey, which is widely used in the international scientific and policy communities, is regarded as being of very high quality. It is designed to represent the population at the "kabupaten" (district) level. The baseline for STAR consists of households located in 13 districts along the coast of Aceh and North Sumatra when they were interviewed in the 2004 (preearthquake) wave of SUSENAS. We selected these 13 districts because they were geographically positioned so that their coastlines were at risk of inundation from the tsunami waves although not all parts of the coast were, in fact, inundated. This provides communities that were directly impacted by the tsunami and coastal communities that were not directly affected. Within these 13 districts, all SUSENAS enumeration areas were included in STAR, for a total of 410 enumeration areas (EAs) in 369 villages. Although all of the districts included in STAR had a potentially vulnerable coastline, the extent to which the tsunami inundated the 410 enumeration areas varied considerably as a function of position relative to the earthquake's epicenter, shape of the coastline, distance from the ocean, elevation of the land, and the presence of rivers or canals flowing into the ocean.

To characterize the tsunami's destructive effect on each enumeration area, we developed a classification method that combines information from remote-sensed satellite imagery, reports from community informants, and observations of survey team supervisors. We use several biophysical measures derived from satellite images, which were linked to the exact location of each EA using global positioning system (GPS) measurements made during the follow-up survey. We constructed one of these measures by comparing satellite imagery from the National Aeronautics and Space Administration's Moderate Resolution Imaging Spectroradiometer (MODIS) for 17 December 2004, a week before the tsunami, to imagery for 29 December 2004, 3 days after the tsunami. The proportion of land cover that the tsunami changed to bare earth (through scouring or sediment deposition) was manually assessed for a $0.6-\mathrm{km}^{2}$ area centered over each GPS point. These estimates of damage were cross-validated with estimates of damaged areas derived from remotely sensed imagery and prepared by the United States Geological Survey, the United States Agency for International Development, the Dartmouth Flood Observatory, and the German Aerospace Center (Gillespie et al. 2007). Additionally, in each community, we conducted interviews with local leaders, who provided their own assessments of the extent of destruction to the built and natural environment due to the tsunami and earthquake, and our survey supervisors completed a questionnaire that detailed damage due to the tsunami and earthquake based on their own direct observation.

We used these sources of information to construct a categorical indicator of damage to the enumeration area. This indicator is a strong and significant predictor of many tsunami-related outcomes derived from the household data including mortality, injuries, post-traumatic stress disorders, and extent of damage to houses and land (Frankenberg et al. 2008). By this indicator, 95 of the 410 STAR enumeration areas are classified as severely damaged. We conducted the analyses for this paper based on data from respondents who were living in the severely damaged areas at the time of the pre-earthquake baseline.

Before the earthquake, when interviewed as part of the 2004 baseline survey, one respondent in each household reported socioeconomic and demographic characteristics for themselves and all other household members. The first followup survey, STAR1, took place between May 2005 and July 2006, in collaboration with Statistics Indonesia and with the assistance of their field supervisors. In STAR1, we collected both individual and household-level data, drawing on and augmenting the baseline questionnaire. Every adult member of every household was eligible to be interviewed, and information about every child was collected from a parent or primary caretaker. Every member of the baseline household survey who survived the tsunami was eligible to be tracked and interviewed in their new location. In addition, village leaders and informants at local schools and health facilities provided information as part of a large community-level survey.

STAR1 was the first of five annual post-tsunami surveys. These data are combined with the subsequentr waves, STAR2 -STAR5, the last of which took place between September 2009 and December 2010.

In this paper, we focus on 3,812 individuals who were between 20 and 59 years old at the time of the baseline survey and were living in the 95 enumeration areas classified as heavily damaged. We put enormous effort into identifying the baseline respondents who had died in the tsunami, which involved finding surviving members of baseline households, following up with neighbors and community leaders in the devastated areas, visiting camps and barracks, and consulting registers kept in each village of those who died or were missing (see Frankenberg et al. 2011 for more details). Of all the deaths 
recorded in STAR and attributed to the tsunami, 92\% occurred in the severely damaged enumeration areas on which we focus here.

High re-interview rates are critical to the success of longitudinal surveys. We developed and implemented extensive tracking protocols to find not only those who continued to live in their baseline locations but also those who moved. This is particularly important in the context of a disaster that causes massive disruption and displacement-as is the case with the tsunami.

Of the age-eligible respondents who were, at baseline, living in the severely damaged areas, $28 \%$ were dead as of the first follow-up survey. Of the remaining respondents, $87 \%$ were members of interviewed households in the first follow-up. Persistent attempts to track all survivors in subsequent waves paid off: over $95 \%$ have been interviewed at least once and 90\% were assessed in the final interview.

\section{Measures}

In this section, we describe the measures that we use to indicate vulnerability to the immediate and shorter term impacts of the tsunami, as well measures that capture longer term outcomes and can be interpreted as indicators of resilience.

As the water came ashore, it swept up many people, killing some, exposing others to traumatic experiences, and damaging or destroying most of the homes in its path. Measures of these outcomes serve as indicators of the disaster's immediate impact. We begin by examining mortality. Among those who survived, we also analyze experiences during the tsunami, including hearing or seeing the water come ashore, being caught in the water or injured by it, seeing others struggling in the water, or having one's house damaged or destroyed as a result of the disaster.

In the months that followed the tsunami, residents of the communities that were heavily damaged struggled to cope with the magnitude of the event, and assistance began to arrive. To capture these dynamics, we focus on two dimensions: the built environment and psychosocial resources.

With respect to the built environment, damage to housing and infrastructure from the tsunami resulted in massive population displacement. We analyze whether respondents were displaced from their original residence and, if they were, whether they lived in temporary housing (defined as living in a camp or temporary settlement, a tent, or barracks) at some point during the 2 years after the tsunami. We also investigate whether they received assistance from the government or international agencies to build or repair housing.

With respect to psychosocial resources, we develop indicators of post-traumatic stress reactivity (PTSR) and receipt of mental health counseling. We believe it appropriate to focus on PTSR because it is one of the most common psychological sequelae of exposure to disasters and because higher levels of socioeconomic status, as measured by education and other indicators, have been shown to be protective in previous studies (Armenian et al. 2000; see also Norris et al. 2002 for a review). The stress measures are constructed from information on post-traumatic stress reactions, which were assessed using seven items from the 17-item Post-Traumatic Stress Disorder (PTSD) Checklist Civilian Version (PCL) (Weathers et al. 1993). The instrument has been validated among veterans, those exposed to disasters, violence, accidents, and sexual assault, and survivors of bone-marrow transplants and has been used in both advanced and developing countries (Blanchard et al. 1996, Smith et al. 1999). Adult respondents in the post-tsunami surveys were asked about specific symptom items that, in combination, covered three distinctive psychological domains of post-traumatic stress. These data were used to construct PTSR scales developed in Frankenberg et al. (2008), which range from 0 to 21. Higher values reflect higher PTSR, and thus poorer psychosocial health. Psychosocial counseling has been shown to mitigate the effects of disasters on psychosocial well-being, and efforts were made to strengthen mental health services in Aceh in the years following the disaster (Prasetiyawan et al. 2006). We assess who obtained counseling.

Our final set of indicators of well-being provides a summary of the economic status of each respondent and their families. Income is often used as a measure of economic well-being in socioeconomic studies, but it is complicated to interpret, particularly after the tsunami destroyed farmland and businesses, resulting in a substantial decline in employment and earnings. Moreover, a large fraction of the populationespecially women — did not earn income before the tsunami.

For these reasons, we examine economic resources at the household rather than individual level. Because a large aid effort was mounted after the tsunami, it is important that the measure of economic well-being include assistance from the public sector as well as from friends and family. A measure that meets these criteria is household consumption, which includes the imputed value of goods produced at home and goods and services provided in kind, during the month before the survey. The value (market and imputed) of consumption is more likely to reflect economic well-being than income as it incorporates not only goods and services provided by family, friends, and the public sector but also consumption from drawing on savings or selling assets.

Another advantage of household consumption is that it is measured in every wave of the survey, including the baseline. Accordingly, we can trace the evolution of expenditure, and its relationship to education, before and after the tsunami. Generally, we expect households to attempt to mitigate the impact of a large negative shock on their well-being by keeping reductions in consumption to a minimum - that is, smoothing 
consumption over time. If the better educated have more resources that they can call on-from savings, family members, or from other sources-then they are likely to reduce consumption less than those with fewer resources during times when resources are relatively scarce. We will provide direct evidence on this question.

In an effort to take into account variation in consumption with household composition, we adjust expenditure for the number of household members and examine household per capita expenditure (PCE). To evaluate the importance of this approximation, we explore changes in household composition. Per capita expenditure is specified in a logarithmic form because its distribution has a very long right tail, and it is well approximated by the log normal distribution.

We also examine the share of the budget allocated to food. Higher food shares have been interpreted as indicative of lower levels of well-being since at least Engel (1895), and the food share is the foundation of many measures of poverty used across the globe. Food shares provide an alternative indicator of economic well-being that complements the logarithm of $\mathrm{PCE}$ and, to some extent, takes into account changes in prices.

\section{EMPIRICAL METHODS}

The goal of this research is to provide new insights into the moderating effect of education in the face of a major shock to population health and well-being as a result of a large and unanticipated disaster. For each outcome, $\theta$, described in the previous section, we examine its association with education, $E$, after adjusting for age, $X$, in a multivariate regression framework. We control for age because, in the study sample, levels of education are significantly higher among younger cohorts. In all analyses based on individual-level data, models are stratified by sex. All models also control location of residence at baseline in a flexible way.

The impacts of some disasters accrue disproportionately in communities whose locations on marginal land make them relatively vulnerable and whose residents tend to be poor and perhaps poorly educated. This was not generally the case with respect to the tsunami, which affected wealthy communities of business owners, and public servants located in cites along the coast as well as relatively poorer communities of fishermen and farmers, but left the more remote inland communities untouched. However, rather than rely on heterogeneity in education levels across communities that were all badly damaged, we draw contrasts among people who were living in the same community. Formally, all of the regression models include community (enumeration area) fixed effects, $\mu_{c}$, which absorb the influence of all community-specific variation that does not change over time and affects the outcome, $\theta$, in a linear and additive way. These fixed effects capture the extent of damage in the community because of the earthquake and tsunami, as well as prior levels of infrastructure and economic activity, and help ensure that individual-level measures of education are not simply proxying for community-level variations in resources before the disaster or degree of destruction during the disaster.

For each individual, $\mathrm{i}$, at time $\mathrm{t}$, the model

$\theta_{i t}=\alpha+\beta E_{i t}+\gamma X_{i t}+\mu_{c}+\varepsilon_{i c t}[1]$

is estimated by ordinary least squares. Unobserved heterogeneity is captured by $\varepsilon_{i c t}$. Estimates of variancecovariance matrices and all test statistics take into account clustering at the enumeration area level and are robust to arbitrary forms of heteroskedasticity (Huber 1981).

Education is measured by the highest grade attained. We interpret grade attained as a crude summary of the respondent's school-related level of human capital, but fully recognize that human capital is a far broader concept that reflects a wide array of skills, personality traits, health, and cognition. Because this research focuses on the relationship between education and each of the outcomes described above, we have carefully explored the shape of this relationship. Two model specifications are reported in the tables. The first model is linear in education and the second is piecewise linear with a knot at completion of grade 6. (Experiments with knots at other points and models that include indicator variables for education do not yield additional insights, and so we report these specifications.)

Table 1 reports the distribution of education of respondents in the baseline survey, conducted before the tsunami, and includes both those who survived the tsunami and those who did not. As shown in Table 1, among all respondents who were living, at baseline, in communities that were severely damaged by the tsunami (the study sample used in the regression analyses reported below), the average respondent completed 9.4 grades of school. This is equivalent to finishing junior secondary school. In contrast, the average respondent in the entire STAR sample of baseline respondents-which includes areas that were not severely damaged-has completed 8.3 grades of school. This difference underscores the fact that, unlike many natural disasters, education levels were on average higher in the areas that were more likely to be severely damaged by the tsunami.

The distribution of education of male and female adults who were living in severely damaged areas is displayed in panel B of Table 1. Very few adults in the sample had no schooling. Among the one-third who had some primary education, the vast majority completed primary school (six grades). About one in five attended junior high school (grades 7-9), about one-quarter attended senior high (grades 10-12), and slightly over one in six attended some college. Males are significantly better educated than females, with $49 \%$ of males in the sample attending senior high school or more, vs. only $42 \%$ of females. 
Table 1. Distribution of age and education

\begin{tabular}{|c|c|c|c|}
\hline & All sample & Females & Males \\
\hline \multicolumn{4}{|l|}{ A. Highest completed grade } \\
\hline 1. All areas & $\begin{array}{c}8.3 \\
{[0.03]}\end{array}$ & $\begin{array}{c}8.0 \\
{[0.05]}\end{array}$ & $\begin{array}{c}8.7 \\
{[0.05]}\end{array}$ \\
\hline 2. Severely damaged areas & $\begin{array}{c}9.4 \\
{[0.07]}\end{array}$ & $\begin{array}{c}9.2 \\
{[0.10]}\end{array}$ & $\begin{array}{c}9.7 \\
{[0.09]}\end{array}$ \\
\hline \multicolumn{4}{|c|}{$\begin{array}{l}\text { B. Grade completed (\% sample) } \\
\text { (among respondents in severely damaged areas) }\end{array}$} \\
\hline No school & 1.8 & 2.6 & 1.0 \\
\hline Some primary school (Grade $1-5$ ) & 8.6 & 9.0 & 8.1 \\
\hline Completed primary school (Grade 6) & 23.6 & 26.2 & 21.0 \\
\hline Junior secondary school (Grades 7-9) & 20.5 & 19.9 & 21.1 \\
\hline Senior secondary school (Grades 10-12) & 27.8 & 24.2 & 31.5 \\
\hline College (>Grade 12$)$ & 17.6 & 18.1 & 17.1 \\
\hline \multicolumn{4}{|l|}{ Age (\% sample) } \\
\hline $20-29$ & 35.9 & 38.0 & 33.7 \\
\hline 30-39 & 30.2 & 29.4 & 31.1 \\
\hline $40-49$ & 20.8 & 20.4 & 21.3 \\
\hline $50-59$ & 13.0 & 12.1 & 13.9 \\
\hline Sample size & 3415 & 1732 & 1683 \\
\hline
\end{tabular}

Notes: [Standard errors].

The table also displays the age distribution of baseline respondents, with about one-third in their twenties, one-third in their thirties, and the rest in their forties and fifties.

\section{RESULTS}

This section presents results from estimating the regression model described above, which provides a summary of how educational attainment is related to outcomes that represent both vulnerability to the tsunami's immediate and short-term impacts and longer-term resilience in the disaster's aftermath. Attention is restricted to respondents who were, at the time of the pre-tsunami baseline survey, living in enumeration areas that were subsequently severely damaged by the tsunami. The samples include those who stayed in the areas and those who moved away so that they are representative of the population exposed to the full brunt of the tsunami.

Table 2 presents the results of estimating the model for our measures of the tsunami's immediate impact: mortality, exposure to traumatic experiences, and damage or destruction to housing. In the table (and in subsequent tables for other outcomes), panel A displays the average for the outcome. Mortality in the heavily damaged areas was extremely high: $30.2 \%$ of females and $19.1 \%$ of males died in the tsunami. Close to the coast, mortality was even higher. In communities within a kilometer of the shoreline, $54.5 \%$ of females and $33.3 \%$ of males died.

Panel B displays estimates of the shape of the relationship between education and each outcome, controlling age and EA fixed effects. Panel B1 reports estimates from a model that is linear in education. Panel B2 reports estimates from a spline function that allows the shape to be piece-wise linear in education with a knot at completed grade 6 (or completed primary school). Sample sizes are in panel C.

For females, education does not confer a survival advantage. Better-educated females are no more likely to survive the tsunami than females with little education (column 1). For males, some evidence suggests that education is protective, at least among those who advanced beyond primary school (column 2). Males who completed senior high school are about 6.5 percentage points more likely to survive the tsunami than those who left school after completing primary education. However, those who completed primary school are themselves about 8 percentage points more likely to die in the tsunami than those who never attended school.

One interpretation of these results is that, in part, the mortality differences by education of males reflect differences in height, strength, and possibly other dimensions of human capital. This interpretation is consistent with the evidence that mortality rates are higher among females than among males. As shown in Frankenberg et al. (2011), older males and females were also more likely to die in the tsunami relative to prime age males and females, respectively.

To explore the idea that education may be an important proxy for strength, we re-estimate the models for respondents who were living within $1 \mathrm{~km}$ of the coast, where mortality was 
Table 2. Mortality and exposure at time of the tsunami

\begin{tabular}{|c|c|c|c|c|c|c|c|c|c|c|c|}
\hline \multicolumn{4}{|c|}{ I. Mortality at time of tsunami } & \multicolumn{6}{|c|}{ II. Exposure at time of tsunami } & \multicolumn{2}{|c|}{$\begin{array}{c}\text { III. Damaged/ } \\
\text { Destroyed Housing }\end{array}$} \\
\hline \multicolumn{2}{|c|}{ All respondents } & \multicolumn{2}{|c|}{$\leq 1 \mathrm{~km}$ from coast } & \multicolumn{3}{|c|}{ Females } & \multicolumn{3}{|c|}{ Males } & \multirow{2}{*}{$\begin{array}{c}\text { Females } \\
\\
{[11]}\end{array}$} & \multirow{2}{*}{$\begin{array}{r}\text { Males } \\
\\
{[12]} \\
\end{array}$} \\
\hline Females & Males & Females & Males & $\begin{array}{c}\text { Injured or } \\
\text { caught in the } \\
\text { water } \\
{[5]}\end{array}$ & $\begin{array}{c}\text { See others } \\
\text { struggle } \\
{[6]} \\
\end{array}$ & $\begin{array}{c}\text { Hear or see } \\
\text { the water } \\
{[7]}\end{array}$ & $\begin{array}{c}\text { Injured or } \\
\text { caught in the } \\
\text { water } \\
{[8]}\end{array}$ & $\begin{array}{c}\begin{array}{c}\text { See others } \\
\text { struggle }\end{array} \\
{[9]}\end{array}$ & $\begin{array}{c}\text { Hear or see } \\
\text { the water } \\
{[10]}\end{array}$ & & \\
\hline \multicolumn{12}{|l|}{ A. Mean } \\
\hline $\begin{array}{c}30.2 \\
{[3.62]}\end{array}$ & $\begin{array}{c}19.1 \\
{[2.41]}\end{array}$ & $\begin{array}{c}54.5 \\
{[8.33]}\end{array}$ & $\begin{array}{c}33.3 \\
{[7.15]}\end{array}$ & $\begin{array}{c}25.9 \\
{[2.75]}\end{array}$ & $\begin{array}{c}35.5 \\
{[3.30]}\end{array}$ & $\begin{array}{c}76.8 \\
{[3.52]}\end{array}$ & $\begin{array}{c}34.6 \\
{[2.77]}\end{array}$ & $\begin{array}{c}44.6 \\
{[3.03]}\end{array}$ & $\begin{array}{c}80.8 \\
{[3.03]}\end{array}$ & $\begin{array}{l}63.47 \\
{[3.87]}\end{array}$ & $\begin{array}{l}76.39 \\
{[4.00]}\end{array}$ \\
\hline \multicolumn{12}{|c|}{ B. Education (highest grade) } \\
\hline $\begin{array}{c}\text { B.1 Linear } \\
-0.05 \\
{[0.17]}\end{array}$ & $\begin{array}{l}-0.59 \\
{[0.22]}\end{array}$ & $\begin{array}{l}-0.38 \\
{[0.44]}\end{array}$ & $\begin{array}{l}-1.58 \\
{[0.63]}\end{array}$ & $\begin{array}{l}-0.79 \\
{[0.39]}\end{array}$ & $\begin{array}{l}-0.71 \\
{[0.45]}\end{array}$ & $\begin{array}{l}-0.02 \\
{[0.32]}\end{array}$ & $\begin{array}{l}-0.10 \\
{[0.44]}\end{array}$ & $\begin{array}{l}-0.45 \\
{[0.44]}\end{array}$ & $\begin{array}{l}-0.24 \\
{[0.31]}\end{array}$ & $\begin{array}{c}0.02 \\
{[0.28]}\end{array}$ & $\begin{array}{l}-0.62 \\
{[0.37]}\end{array}$ \\
\hline \multicolumn{12}{|c|}{ B.2 Spline (0-6) } \\
\hline $\begin{array}{c}-0.42 \\
{[0.44]}\end{array}$ & $\begin{array}{c}1.16 \\
{[0.65]}\end{array}$ & $\begin{array}{l}-1.14 \\
{[1.29]}\end{array}$ & $\begin{array}{c}0.17 \\
{[2.45]}\end{array}$ & $\begin{array}{l}-0.23 \\
{[0.98]}\end{array}$ & $\begin{array}{l}-0.73 \\
{[0.87]}\end{array}$ & $\begin{array}{l}-0.22 \\
{[0.61]}\end{array}$ & $\begin{array}{c}0.95 \\
{[0.97]}\end{array}$ & $\begin{array}{l}-0.40 \\
{[1.16]}\end{array}$ & $\begin{array}{c}0.29 \\
{[0.81]}\end{array}$ & $\begin{array}{c}0.45 \\
{[0.70]}\end{array}$ & $\begin{array}{l}-1.04 \\
{[0.63]}\end{array}$ \\
\hline \multicolumn{12}{|l|}{ Spline $(\geq 7)$} \\
\hline $\begin{array}{c}0.09 \\
{[0.28]}\end{array}$ & $\begin{array}{l}-1.07 \\
{[0.29]}\end{array}$ & $\begin{array}{l}-0.09 \\
{[0.81]}\end{array}$ & $\begin{array}{l}-2.07 \\
{[0.84]}\end{array}$ & $\begin{array}{c}-0.96 \\
{[0.48]}\end{array}$ & $\begin{array}{l}-0.70 \\
{[0.56]}\end{array}$ & $\begin{array}{c}0.04 \\
{[0.37]}\end{array}$ & $\begin{array}{l}-0.35 \\
{[0.54]}\end{array}$ & $\begin{array}{c}-0.46 \\
{[0.54]}\end{array}$ & $\begin{array}{l}-0.37 \\
{[0.40]}\end{array}$ & $\begin{array}{l}-0.14 \\
{[0.36]}\end{array}$ & $\begin{array}{l}-0.46 \\
{[0.52]}\end{array}$ \\
\hline \multicolumn{12}{|c|}{ C. Sample size } \\
\hline 1920 & 1889 & 314 & 318 & 1036 & 1036 & 1036 & 1166 & 1166 & 1166 & 1036 & 1166 \\
\hline
\end{tabular}

Notes [Standard errors] take into account clustering at the enumeration area level and are robust to heteroskedasticity. Includes controls for respondent age and enumeration area fixed effects.

highest. Results are reported in columns 3 and 4 . Close to the coast, education is unrelated to survival for females but is even more strongly predictive of survival among males, suggesting that strength is not the full explanation for the link between education and survival.

We cannot test directly whether education is a proxy for height and strength because neither height nor strength was measured at baseline and, therefore, is not known for those who died in the tsunami. However, using data from areas that were not damaged by the tsunami, where mortality is very low, we can estimate the association between height and education using data from the post-tsunami resurveys. On average, a male who completed senior high is $163 \mathrm{~cm}$ tall; a male who only completed primary school is $160 \mathrm{~cm}$ tall and a male who did not complete primary school is $142 \mathrm{~cm}$ tall. Controlling age, in a piece-wise linear specification, each year of education is associated with a $4.7 \mathrm{~cm}$ (standard error $=0.3 \mathrm{~cm}$ ) increase in height until completing primary school and then an increase of $0.3 \mathrm{~cm}$ ( standard error $=0.08 \mathrm{~cm}$ ) for each additional grade thereafter. Because the association between education and mortality is positive for males up to completion of primary school and is then negative and significant only for males with more than primary schooling (whereas the association between education and height is positive throughout the education distribution), it seems unlikely that education serves only as a proxy for height and strength in these regression models. The education-height association is not strong enough nor the appropriate shape to fully explain the relationship between survival and education of males.
All subsequent regression analyses focus on those who survived the tsunami. Many of the survivors experienced harrowing events as the water came ashore. We next turn to the question of how education is related to these experiences, as reported by survivors who were living at baseline in areas that were subsequently severely damaged by the tsunami (these results are presented in columns 5 through 10 of Table 2). We begin with females. Overall, a quarter of women were caught up in the water or injured, just over one-third witnessed others struggling in the water, and about three-quarters heard or saw the water come ashore. Better-educated women were less likely to report being caught in the water, injured, or watching others struggle. For example, a female who completed senior high school is estimated to be between 4 and 5 percentage points less likely to have been caught up in or injured by the water relative to a female who completed primary school, and this difference is statistically significant. Education is unrelated to hearing or seeing the tsunami come ashore among females.

Among male survivors about one-third report being caught up in the water or injured, and nearly $45 \%$ saw others struggling in the water. These rates are higher than for females because females were less likely to have lived to report these experiences than were males. For males, conditional on surviving, exposure to the tsunami is unrelated to education.

The results presented thus far relate to the vulnerability of individuals along the health-related dimensions of mortality and exposure to traumatic experiences. The physical 
Table 3. Displacement and receipt of housing assistance

\begin{tabular}{|c|c|c|c|c|c|c|}
\hline & \multicolumn{3}{|c|}{ Females } & \multicolumn{3}{|c|}{ Males } \\
\hline & $\begin{array}{c}\text { Displaced by } \\
\text { tsunami } \\
{[1]} \\
\end{array}$ & $\begin{array}{c}\text { Lived in temporary } \\
\text { housing } \\
{[2]} \\
\end{array}$ & $\begin{array}{c}\text { Received housing } \\
\text { assistance } \\
{[3]} \\
\end{array}$ & $\begin{array}{c}\text { Displaced by } \\
\text { tsunami } \\
{[4]} \\
\end{array}$ & $\begin{array}{c}\text { Lived in temporary } \\
\text { housing } \\
{[5]}\end{array}$ & $\begin{array}{c}\text { Received housing } \\
\text { assistance } \\
{[6]} \\
\end{array}$ \\
\hline A. Mean & $\begin{array}{l}66.25 \\
{[5.45]}\end{array}$ & $\begin{array}{l}46.33 \\
{[4.37]}\end{array}$ & $\begin{array}{c}51.25 \\
{[4.43]}\end{array}$ & $\begin{array}{l}66.47 \\
{[4.13]}\end{array}$ & $\begin{array}{l}52.06 \\
{[3.95]}\end{array}$ & $\begin{array}{l}55.75 \\
{[4.10]}\end{array}$ \\
\hline B. Education (hig & & & & & & \\
\hline B.1 Linear & $\begin{array}{c}0.17 \\
{[0.36]}\end{array}$ & $\begin{array}{l}-1.31 \\
{[0.44]}\end{array}$ & $\begin{array}{l}-0.78 \\
{[0.37]}\end{array}$ & $\begin{array}{l}-0.39 \\
{[0.41]}\end{array}$ & $\begin{array}{l}-1.39 \\
{[0.37]}\end{array}$ & $\begin{array}{l}-0.84 \\
{[0.39]}\end{array}$ \\
\hline B.2 Spline (0-6) & $\begin{array}{c}1.22 \\
{[0.92]}\end{array}$ & $\begin{array}{l}-1.64 \\
{[0.86]}\end{array}$ & $\begin{array}{l}-1.73 \\
{[1.03]}\end{array}$ & $\begin{array}{l}-0.73 \\
{[0.73]}\end{array}$ & $\begin{array}{l}-0.47 \\
{[0.88]}\end{array}$ & $\begin{array}{l}-0.57 \\
{[0.83]}\end{array}$ \\
\hline Spline $(\geq 7)$ & $\begin{array}{l}-0.11 \\
{[0.42]}\end{array}$ & $\begin{array}{l}-1.21 \\
{[0.46]}\end{array}$ & $\begin{array}{l}-0.50 \\
{[0.48]}\end{array}$ & $\begin{array}{l}-0.30 \\
{[0.52]}\end{array}$ & $\begin{array}{l}-1.61 \\
{[0.41]}\end{array}$ & $\begin{array}{l}-0.90 \\
{[0.49]}\end{array}$ \\
\hline C. Sample size & 1036 & 1036 & 1036 & 1166 & 1166 & 1166 \\
\hline
\end{tabular}

Notes [Standard errors] take into account clustering at the enumeration area level and are robust to heteroskedasticity. Controls included for respondent age and enumeration area fixed effects.

vulnerability of respondents' homes is another dimension with strong implications for the well-being of survivors. The last two columns present results for experiencing damage or destruction to one's home. Overall, two-thirds of women and three-quarters of men report that their home was damaged or destroyed by the tsunami-again reflecting differential survival rates of men and women. But for neither men nor women are damage or destruction of housing related to level of education.

We turn next to outcomes that represent respondents' experiences as the aftermath of the disaster unfolded. We explore these along the dimensions discussed above: housing and psychosocial health. Table 3 focuses on housing in the disaster's aftermath. Whereas the models are reported separately for males and females, results do not differ by sex, and so we do not distinguish between males and females in the discussion.

We first consider displacement, which we define as moving within the first 4 months following the tsunami. About twothirds of survivors were displaced by the tsunami, and being displaced is not associated with education.

About half the survivors who were living in areas that were severely damaged lived in temporary housing - typically a camp_at some point during the 2 years after the tsunami (columns 2 and 5). The rest of the displaced moved to private homes-either moving in with family or friends or renting a private home. The better educated, particularly those who completed more than primary school, were significantly less likely to move to temporary housing, but this is not because the better educated were less likely to be displaced. Displacement risks are not related to education. Rather, the education advantage with respect to avoiding temporary shelter likely reflects the greater availability of financial and/ or social resources of those who are better educated.
A key dimension of the recovery and reconstruction effort was the provision of assistance with building or repairing houses that were damaged or destroyed by the tsunami. About half of the tsunami survivors received housing assistance from the government or a nongovernmental organization (NGO) - a fraction that is substantially less than the fraction whose houses were damaged. The better educated were just as likely to have their home damaged in the tsunami, but they were less likely to receive housing assistance. Although the decline in the probability of receiving aid as education increases is statistically significant, the rate of decline is small, and differences in the probability of receiving assistance for the best educated relative to those with little education are modest.

Another form of assistance, but one that relates to psychosocial dimensions of the disaster, is receipt of mental health counseling. As shown in the first two columns of Table 4, regardless of sex, around one in six survivors received some form of counseling after the tsunami. Although the relationship between education and receipt of counseling is positive, the association is only statistically significant for males who completed more than primary schooling.

Columns 3 through 6 of Table 4 report levels of PTSR. At the time of the first interview after the tsunami, levels of PTSR are higher among females (6.60 on a scale of 21) than among males (5.89). For neither sex are there differences across the education distribution. At the time of the most recent interview, approximately 5 years later, PTSR levels have declined substantially, although they remain higher for females relative to males (3.63 vs. 2.73 on the same 21 -point scale). In addition, PTSR is significantly lower among the better educated, indicating that those with more education are more resilient in terms of psychosocial well-being. For example, the difference in PTSR of a male who completed senior high school relative to a male who did not attend school is about half the average level of PTSR for all males at the 
Table 4. Mental health counseling and post-traumatic stress reactivity

\begin{tabular}{|c|c|c|c|c|c|c|}
\hline & \multicolumn{2}{|c|}{ I. Received mental health counselling } & \multicolumn{4}{|c|}{ II. Post-Traumatic Stress Reactivity } \\
\hline & \multirow{2}{*}{$\begin{array}{c}\text { Females } \\
\text { At any time during } \\
\text { study period } \\
{[1]}\end{array}$} & \multirow{2}{*}{$\begin{array}{c}\text { Males } \\
\text { At any time during } \\
\text { study period } \\
{[2]} \\
\end{array}$} & \multicolumn{2}{|c|}{ Females } & \multicolumn{2}{|c|}{ Males } \\
\hline & & & $\begin{array}{c}\text { First interview afer } \\
\text { tsunami } \\
{[3]} \\
\end{array}$ & $\begin{array}{c}\text { Last } \\
\text { interview } \\
{[4]} \\
\end{array}$ & $\begin{array}{c}\text { First interview after } \\
\text { tsunami } \\
{[5]} \\
\end{array}$ & $\begin{array}{c}\text { Last } \\
\text { interview } \\
{[6]} \\
\end{array}$ \\
\hline A. Mean & $\begin{array}{l}14.58 \\
{[1.63]}\end{array}$ & $\begin{array}{c}13.38 \\
{[1.42]}\end{array}$ & $\begin{array}{c}6.60 \\
{[0.16]}\end{array}$ & $\begin{array}{c}3.63 \\
{[0.21]}\end{array}$ & $\begin{array}{c}5.89 \\
{[0.17]}\end{array}$ & $\begin{array}{c}2.73 \\
{[0.16]}\end{array}$ \\
\hline \multicolumn{7}{|c|}{ B. Education (highest grade) } \\
\hline B.1 Linear & $\begin{array}{c}0.34 \\
{[0.30]}\end{array}$ & $\begin{array}{c}0.50 \\
{[0.30]}\end{array}$ & $\begin{array}{c}0.06 \\
{[0.05]}\end{array}$ & $\begin{array}{l}-0.08 \\
{[0.03]}\end{array}$ & $\begin{array}{l}-0.03 \\
{[0.04]}\end{array}$ & $\begin{array}{l}-0.11 \\
{[0.03]}\end{array}$ \\
\hline B.2 Spline $(0-6)$ & $\begin{array}{c}0.73 \\
{[0.74]}\end{array}$ & $\begin{array}{l}-0.50 \\
{[0.95]}\end{array}$ & $\begin{array}{l}-0.02 \\
{[0.12]}\end{array}$ & $\begin{array}{c}0.05 \\
{[0.10]}\end{array}$ & $\begin{array}{c}0.02 \\
{[0.10]}\end{array}$ & $\begin{array}{l}-0.19 \\
{[0.09]}\end{array}$ \\
\hline Spline $(\geq 7)$ & $\begin{array}{c}0.23 \\
{[0.38]}\end{array}$ & $\begin{array}{c}0.74 \\
{[0.33]}\end{array}$ & $\begin{array}{c}0.08 \\
{[0.06]}\end{array}$ & $\begin{array}{l}-0.11 \\
{[0.04]}\end{array}$ & $\begin{array}{l}-0.04 \\
{[0.05]}\end{array}$ & $\begin{array}{l}-0.09 \\
{[0.04]}\end{array}$ \\
\hline C. Sample size & 1036 & 1166 & 860 & 860 & 829 & 829 \\
\hline
\end{tabular}

Notes [Standard errors] take into account clustering at the enumeration area level and are robust to heteroskedasticity. Controls included for respondent age and enumeration area fixed effects.

final interview; for females, a comparable comparison accounts for about one-quarter of the average PTSR level.

In Table 5, we turn to indicators of the characteristics of households that respondents are in at each wave of the study. These characteristics include the logarithm of PCE, InPCE, the share of spending that goes to food, household size, and the share of household members who are under 15. Because these indicators are measured at the household level, models are not estimated separately for males and females. The relationship between $\operatorname{lnPCE}$ and education of the respondent is estimated separately for every wave of the study, which provides evidence on evolution in the trajectory of $1 \mathrm{PCCE}$ across the education distribution as time passes.

Panel 1A of the table reports the association between $\ln P C E$ and education for each wave. Specifying expenditure in logarithms means that the coefficient estimates can be interpreted as representing percentage changes. By estimating the models separately for each year after the tsunami, and by including enumeration area fixed effects, the models absorb the impact of changes in prices over time and at the local area level. This is important in the context of the tsunami-and most natural disasters-when supply chains are severely disrupted and shortages of food, housing, and transport are accompanied by high rates of price inflation that vary across time and space.

In the pre-tsunami wave, the better educated spend more: per capita expenditure is $2.16 \%$ higher for each year of completed education. This is a reflection of the fact that education and economic success are positively correlated. In the year after the tsunami, each year of education was associated with a $4.18 \%$ increase in PCE. The difference between the post- and pre-tsunami association, $2.02 \%$, is displayed in panel $1 \mathrm{~B}$. That difference is statistically significant, indicating that the better educated were substantially better protected from the declines in PCE - and economic resource availability - that occurred in the aftermath of the tsunami. Thus, the better educated were better able to smooth consumption after this large shock, and inequality across the education distribution rose. As years since the tsunami passed, the gap in spending between the better and less educated remained larger than it was before the tsunami, but the difference is significant only during the first 2 years after the tsunami.

The piece-wise linear model, in panel $1 \mathrm{C}$, establishes that consumption smoothing is more effective only among those who have completed primary education. In fact, for those who did not complete primary school, education and PCE are not related.

The interpretation of variation in the relationship between PCE and education is not entirely straightforward. First, immediately after the tsunami, prices rose substantially for many goods and, as a result, relative prices also changed. Changes in overall prices are captured by the intercept. The data to reliably compute such indices do not exist.

If prices of the consumption bundles consumed by the better educated rose more than those consumed by the less educated, then real resources of the better educated will be lower than those of the less educated, and this could explain the apparently greater consumption smoothing by the better educated. This is unlikely to be the case, as prices of food, housing, and transport rose the most, and these goods tend to account for a larger share of the budget of poorer households. Rather, our estimates of the differences in consumption smoothing are likely to be lower bounds because prices for the goods the least educated spend most of their money on are the prices that likely rose the most. 
Table 5. Economic resources and household composition

\begin{tabular}{|c|c|c|c|c|c|c|}
\hline \multirow[t]{2}{*}{ Survey wave } & \multirow{2}{*}{$\begin{array}{c}\text { Pre- } \\
\text { tsunami } \\
{[1]}\end{array}$} & \multicolumn{5}{|c|}{ Post-tsunami survey wave (years after tsunami) } \\
\hline & & $\begin{array}{c}1 \\
{[2]}\end{array}$ & $\begin{array}{c}2 \\
{[3]}\end{array}$ & $\begin{array}{c}3 \\
{[4]}\end{array}$ & $\begin{array}{c}4 \\
{[5]}\end{array}$ & $\begin{array}{c}5 \\
{[6]}\end{array}$ \\
\hline \multicolumn{7}{|l|}{ 1. $\ln \mathrm{PCE}$} \\
\hline 1A. Education & $\begin{array}{c}2.16 \\
{[0.30]}\end{array}$ & $\begin{array}{c}4.18 \\
{[0.67]}\end{array}$ & $\begin{array}{c}3.51 \\
{[0.47]}\end{array}$ & $\begin{array}{c}3.07 \\
{[0.50]}\end{array}$ & $\begin{array}{c}2.90 \\
{[0.48]}\end{array}$ & $\begin{array}{c}2.74 \\
{[0.44]}\end{array}$ \\
\hline 1B. Difference (relative to pre-tsunami relationship) & & $\begin{array}{c}2.02 \\
{[0.73]}\end{array}$ & $\begin{array}{c}1.34 \\
{[0.55]}\end{array}$ & $\begin{array}{c}0.91 \\
{[0.58]}\end{array}$ & $\begin{array}{c}0.73 \\
{[0.56]}\end{array}$ & $\begin{array}{c}0.57 \\
{[0.53]}\end{array}$ \\
\hline 1C. Spline $(0-6)$ & $\begin{array}{l}-0.01 \\
{[0.66]}\end{array}$ & $\begin{array}{c}1.10 \\
{[1.59]}\end{array}$ & $\begin{array}{c}0.44 \\
{[1.54]}\end{array}$ & $\begin{array}{c}1.44 \\
{[1.01]}\end{array}$ & $\begin{array}{c}0.47 \\
{[0.95]}\end{array}$ & $\begin{array}{c}1.46 \\
{[1.06]}\end{array}$ \\
\hline Spline $(\geq 7)$ & $\begin{array}{c}2.74 \\
{[0.34]}\end{array}$ & $\begin{array}{c}4.96 \\
{[0.87]}\end{array}$ & $\begin{array}{c}4.30 \\
{[0.54]}\end{array}$ & $\begin{array}{c}3.50 \\
{[0.64]}\end{array}$ & $\begin{array}{c}3.52 \\
{[0.57]}\end{array}$ & $\begin{array}{c}3.07 \\
{[0.56]}\end{array}$ \\
\hline \multicolumn{7}{|l|}{ 2. Food share } \\
\hline Spline $(0-6)$ & $\begin{array}{c}0.06 \\
{[0.18]}\end{array}$ & $\begin{array}{l}-0.13 \\
{[0.33]}\end{array}$ & $\begin{array}{l}-0.17 \\
{[0.36]}\end{array}$ & $\begin{array}{l}-0.38 \\
{[0.27]}\end{array}$ & $\begin{array}{c}-0.34 \\
{[0.28]}\end{array}$ & $\begin{array}{c}0.01 \\
{[0.27]}\end{array}$ \\
\hline Spline $(\geq 7)$ & $\begin{array}{l}-0.45 \\
{[0.08]}\end{array}$ & $\begin{array}{l}-1.34 \\
{[0.20]}\end{array}$ & $\begin{array}{l}-1.03 \\
{[0.17]}\end{array}$ & $\begin{array}{l}-0.87 \\
{[0.13]}\end{array}$ & $\begin{array}{l}-0.77 \\
{[0.16]}\end{array}$ & $\begin{array}{l}-0.73 \\
{[0.14]}\end{array}$ \\
\hline \multicolumn{7}{|l|}{ 3. Household size } \\
\hline Spline $(0-6)$ & $\begin{array}{c}0.07 \\
{[0.04]}\end{array}$ & $\begin{array}{c}0.09 \\
{[0.04]}\end{array}$ & $\begin{array}{c}0.05 \\
{[0.04]}\end{array}$ & $\begin{array}{c}0.06 \\
{[0.03]}\end{array}$ & $\begin{array}{c}0.03 \\
{[0.03]}\end{array}$ & $\begin{array}{c}0.05 \\
{[0.04]}\end{array}$ \\
\hline Spline $(\geq 6)$ & $\begin{array}{l}0.010 \\
{[0.02]}\end{array}$ & $\begin{array}{r}-0.010 \\
{[0.02]}\end{array}$ & $\begin{array}{l}-0.020 \\
{[0.02]}\end{array}$ & $\begin{array}{c}-0.02 \\
{[0.02]}\end{array}$ & $\begin{array}{l}-0.03 \\
{[0.02]}\end{array}$ & $\begin{array}{c}-0.02 \\
{[0.02]}\end{array}$ \\
\hline 4. Share of $\mathrm{HH}$ members age $<15$ & & & & & & \\
\hline Spline $(0-6)$ & $\begin{array}{c}0.46 \\
{[0.34]}\end{array}$ & $\begin{array}{c}0.88 \\
{[0.41]}\end{array}$ & $\begin{array}{c}0.71 \\
{[0.34]}\end{array}$ & $\begin{array}{c}0.60 \\
{[0.35]}\end{array}$ & $\begin{array}{c}0.51 \\
{[0.37]}\end{array}$ & $\begin{array}{c}0.74 \\
{[0.37]}\end{array}$ \\
\hline Spline $(\geq 6)$ & $\begin{array}{c}0.07 \\
{[0.16]}\end{array}$ & $\begin{array}{l}-0.01 \\
{[0.17]}\end{array}$ & $\begin{array}{l}-0.18 \\
{[0.16]}\end{array}$ & $\begin{array}{l}-0.16 \\
{[0.17]}\end{array}$ & $\begin{array}{c}0.06 \\
{[0.16]}\end{array}$ & $\begin{array}{c}0.05 \\
{[0.17]}\end{array}$ \\
\hline 5. Sample size & 3413 & 2692 & 2641 & 2627 & 2636 & 2732 \\
\hline
\end{tabular}

Notes [Standard errors] take into account clustering at the enumeration area level and are robust to heteroskedasticity. All models include enumeration area fixed effects.

Additional evidence suggests this is the case. As shown in Panel 2 of Table 5, and paralleling results for lnPCE, food shares are unrelated to education for those with primary schooling or less and then decline with education for higher levels. The rate of decline is substantially and significantly greater in the year immediately after the tsunami, rising from $0.5 \%$ per grade of schooling before the tsunami to $1.3 \%$ after the tsunami. Food shares rose the most for the least educated, whereas the better educated were more able to protect their budget allocations to other goods. The estimated rate of decline of foods shares as education increases becomes less steep as time since the tsunami rises, but it remains significantly different from the pre-tsunami rate for 3 years after the tsunami -longer than is the case for lnPCE.

The second reason that interpretation of changes in PCE is complicated is that household size and composition may have changed over time. For the purposes of interpreting the evidence on the lnPCE-education profile, these changes need to differ across the distribution of education. A long literature focuses on the development of equivalence scales that seek to enable direct comparisons of well-being across different household structures. No consensus has been reached on a theoretically and empirically valid approach to this complex problem and so, faute de mieux, we have adjusted expenditure by household size. Rather than rely on some other ad hoc adjustment, we investigate whether there were changes in household size and composition following the tsunami that are systematically related to education.

Panel 3 of Table 5 reports results for household size and Panel 4 reports results for the share of household members who are age under 15. For both cases, there is evidence that household size and the share age under 15 rose with education immediately after the tsunami-but only among those who had no more than primary schooling - the group of people for whom $\operatorname{lnPCE}$ and food shares are not related to education. Among the better educated, there is no evidence that household size or the share age under 15 is related to education or that these associations changed over time. We conclude that variation in household size and composition is not likely to substantially contaminate our interpretation of changes in economic well-being based on variation in InPCE and food shares. That evidence clearly indicates that, relative to those with little education, the better educated were more successful in smoothing consumption-or mitigating the deleterious impact of the tsunami on spending-immediately after the tsunami whereas those with less education took longer to adjust. 


\section{DISCUSSION}

This research has traced out the tsunami's immediate impacts on health and well-being by comparing the markers before and after the tsunami for the same people. We have also traced out the evolution of the same markers during the 5 years after the tsunami. Throughout, we have given special prominence to variation in these trajectories across the distribution of education and, thereby, have provided new insights into the extent to which heterogeneity in resilience and recovery in the aftermath of a major disaster is related to education.

With respect to its immediate impact, we consider the tsunami as a threat to life and property. Education, particularly above the primary level, provides some protection against death for men, but not for women. Conditional on survival, education provides some protection from being caught in the water or injured for women, but not for men. If one assumes that those who perished in the tsunami were caught in the water, then rates of exposure to the tsunami's greatest threats to safety were similar for males and females, and decline with education for both. However, on the dimension of physical destruction of perhaps greatest salience to our respondents-the loss of a home-the better educated are no less likely to suffer than anyone else.

Thus, in terms of the tsunami's immediate impacts, the protective effect of education was limited. But does education distinguish decisions and outcomes in the aftermath of the tsunami?

The role of education varies by outcome. For those with more than a primary school education, increases in education were associated with a reduced likelihood of living in temporary housing in the form of camps, tents, or barracks. This is not because of greater access to housing assistance from official sources for the better educated. In fact, education is associated with a significant reduction in the likelihood of receiving such housing assistance, although the size of the effect is small.

Turning to psychosocial dimensions of well-being, in the period shortly after the tsunami, levels of PTSR did not differ across the education distribution. Over time, however, declines in PTSR proceed more rapidly for the better educated. As with housing, this does not reflect better access to mental health services among the better educated. Receipt of any counseling was rare.

Because data on levels and patterns of household spending are available before the tsunami, as well as annually for 5 years afterward, we investigate the evolution of spending before and after the tsunami, and how those trajectories differ by education level. In the year after the tsunami, absolute levels of spending decline for everyone, but the size of the decline shrinks as education rises. In other words, after the tsunami, the difference in spending levels by education increases, suggesting that the better educated were better able to protect spending after the disaster. But, over time, the difference by education level diminishes. A similar pattern is documented for the share of budget spent on food, an indicator used as a proxy for economic well-being.

Thus, although the tsunami took a huge immediate toll on individuals at all levels of education, the evidence suggests that the better educated were more effective at adjusting to the changed reality of their lives relative to those with less education. In part, this likely reflects the resources they had before the tsunami as well as their experiences in the months after the tsunami, when they were able to afford to move to private homes rather than live in camps. Moreover, although the destruction of livelihoods resulted in reductions in the economic resources of all households, the better educated were more able to mitigate declines in consumption levels relative to the cuts in spending made by those with less education. Finally, 5 years after the tsunami, the better educated were in better psychosocial health than those with less education, indicating a more rapid recovery.

The faster recovery of the better educated in the face of a major natural disaster does not appear to be because they thought an earthquake or tsunami was more likely than those with less education. In the baseline survey conducted before the tsunami, a randomly selected subsample of $15 \%$ of the respondents were asked whether they thought they were living in a location that was at high risk of a natural disaster. In all of Aceh and North Sumatra, $9 \%$ of the respondents answered this question in the affirmative, and $9 \%$ of those respondents said that the greatest risk was from an earthquake or tsunami. In the areas that were severely damaged by the tsunami, $12 \%$ of the respondents said they lived in a place that was at risk of a natural disaster, and $13 \%$ of them indicated the greatest risk was from an earthquake or tsunami. Importantly, for this research, responses to these questions are not associated with the education levels of the respondents.

Instead, the protective effects of education are likely a reflection of greater accumulated financial resources and possibly social resources available to the better educated in times of need. It is also possible that those who have invested more in education make better choices in times of adversity, are more entrepreneurial, and are more effective at taking on new challenges. Although the results presented here are important for the design of policies that seek to mitigate the impact of large-scale disasters, understanding the pathways through which the better educated were more able to weather the storm of the Indian Ocean tsunami remains an important and pressing question for scientific inquiry.

Responses to this article can be read online at: http://www.ecologyandsociety.org/issues/responses. $\mathrm{php} / 5377$ 


\section{Acknowledgments:}

This work has been supported by grants from the World Bank, the MacArthur Foundation (05-85158-000), the National Institute for Child Health and Human Development (HD052762, HD051970), the National Institutes on Aging (AG031266), and the National Science Foundation (CMS-0527763). All opinions and errors are those of the authors.

\section{LITERATURE CITED}

Armenian, H., M. Masahiro, A. Melkonian, A. Hovanesian, N. Haroutunian, P. Saigh, K. Akiskal, and H. Akiskal. 2000. Loss as a determinant of PTSD in a cohort of adult survivors of the 1998 earthquake in Armenia: implications for policy. Acta Psychiatrica Scandinavia 102:58-64.

Blanchard, E.B., J. Jones-Alexander, T. C. Buckley, and C. A. Forneris. 1996. Psychometric properties of the PTSD checklist (PCL). Behavior Research and Therapy 34:669673.

Borrero, O. S. 2005. The great Sumatra earthquake and Indian Ocean tsunami of December 26, 2004. EERI Special Earthquake Report March 2005:1-8.

Bunting, T., C. Chapman, P. Christie, S. Singh, and J. Sledzik. 2007. The science of tsunamis. Oilfield Review Autumn 2007.

Buttenheim A. 2010. Impact evaluation in the post-disaster setting: a case study of the 2005 Pakistan earthquake. Journal of Development Effectiveness 2(2): 197-227.

Doocy, S., Y. Gorokhovich, G. Burnham, D. Balk, and C. Robinson. 2007. Tsunami mortality estimates and vulnerability mapping in Aceh, Indonesia. American Journal of Public Health 97:S146-151. http://dx.doi.org/10.2105/ AJPH.2006.095240

Engel, E. 1895. Die Lebenskosten Belgischer ArbeiterFamilien Fruher and Jetzt. International Statistical Institute Bulletin 9:1-74.

Frankenberg, E., J. Friedman, T. Gillespie, N. Ingwersen, R. Pynoos, I. Rifai, B. Sikoki, A. Steinberg, C. Sumantri, W. Suriastini, and D. Thomas. 2008. Mental health in Sumatra after the tsunami. American Journal of Public Health 98 (9):1671-1677. http://dx.doi.org/10.2105/AJPH.2007.120915

Frankenberg E., T. Gillespie, S. Preston, B. Sikoki, and D. Thomas. 2011. Mortality, the family and the Indian Ocean tsunami. Economic Journal 121(554):F162-182.

Gaillard, J., E. Clavé, O.Vibert, Azhari, Dedi, J. Denain, Y. Efendi, D. Grancher, C. Liamzon, D. Sari, and R. Setiawan.
2008. Ethnic groups' response to the 26 December 2004 earthquake and tsunami in Aceh, Indonesia. Natural Hazards 47(1):17-38.

Galea, S., and A. Maxwell. 2009. Methodological challenges in studying the mental health consequences of disasters. Pages 579-593 in Y. Neria, S. Galea, and F.H. Norris, editors. Mental Health and Disasters. Cambridge University Press, New York, New York, USA.

Gillespie, T., J. Chu, E. Frankenberg, and D. Thomas. 2007. Assessment and prediction of natural hazards from satellite imagery. Progress in Physical Geography 31(5):459-470.

Gray, C., E. Frankenberg, T. Gillespie, C. Sumantri, and D. Thomas. 2011. Population movements in Sumatra after the tsunami. Paper presented at the 2011 Annual Meetings of the Population Association of America, Washington, D.C., USA.

Horton, J. 2011. Natural disasters-taking a longer term view. Lancet 377: 439.

Huber, P. 1981. Robust statistics. Wiley, New York, New York, USA.

Kerr, R. 2005. Model shows island muted tsunami after latest Indonesian quake. Science 308:341.

Kohl, P., A. O'Rourke, D. Schmidman, W. Dopkin, and M. Birnbaum. 2005. The Sumatra-Andaman earthquake and tsunami of 2004: the hazards, events, and damage. Prehospital and Disaster Medicine 20(6):356-363.

Lay, T., H. Kanamori, C. Ammon, M. Nettles, S. Ward, R. Aster, S. Beck, S. Bilek, M. Brudzinski, R. Butler, H. DeShon, G. Ekstrom, K. Satake, and S. Sipkin. 2005. The Great Sumatra-Andaman earthquake of 26 December 2004. Science 308:1127-1133.

Linnerooth-Bayer, J., R. Mechler, and G. Pflug. 2005. Refocusing disaster aid. Science 309(5737): 1044-1046.

Lutz, W., and K. C. Samir. 2011. Global human capital: integrating education and population. Science 333:587-592.

Marris, E. 2005. Inadequate warning system left Asia at the mercy of tsunami. Nature 433:3-5.

Monecke, K., W. Finger, D. Klarer, W. Kongko, B. McAdoo, A. Moore, and S. Sudrajat. 2008. A 1,000-year sediment record of tsunami recurrence in northern Sumatra. Nature 455:12321234.

National Research Council. 2006. Facing hazards and disasters: understanding human dimensions. The National Academies Press, Washington, D.C., USA. 
Norris, F., M. Friedman, P. Watson, C. Byrne, E. Diaz, and K. Kaniasty. 2002. 60,000 disaster victims speak: Part I. An empirical review of the empirical literature. Psychiatry 65 (3):207-239.

Padgett A., and T. Warnecke. 2011. Diamonds in the rubble: the women of Haiti. Institutions, gender equity and human development in Haiti. Journal of Economic Issues XLV(3): 527-558.

Prasetiyawan, E. Viora, A. Maramis, and B. Keliat. 2006. Mental health model of care programmes after the tsunami in Aceh, Indonesia. International Review of Psychiatry 18) 6):559-562.

Ramakrishnan, D., S. Ghosh, V. Raja, R. Vinuchandran, and A. Jeyram. 2005. Trails of the killer tsunami: a preliminary assessment using satellite remote sensing and GIS techniques. Current Science 88(5):709-712.

Rofi, A., S. Doocy, and C. Robinson. 2006. Tsunami mortality and displacement in Aceh province, Indonesia. Disasters 30 (3):340-350.

Sastry, N., and M. Vanlandingham. 2009. Prevalence of and disparities in mental illness among pre-Katrina residents of New Orleans one year after Hurricane Katrina. American Journal of Public Health 99(S3):725-731.

Sinadinovski, C. 2006. The event of $26^{\text {th }}$ December 2004the biggest earthquake in the world in the last 40 years. Bulletin of Earthquake Engineering 4:131-139.

Smith, M.Y., W. Redd, K. DuHamel, S. Vickberg, and P. Ricketts. 1999. Validation of the PTSd checklist-civilian version in survivors of bone marrow transplantation. Journal of Trauma Stress 12(3):485-493.

Strauss, J., and D. Thomas. 2008. Health over the life course. Pages 3375-3474 in T. P. Schultz and J. Strauss, editors. Handbook of development economics, Volume 4. NorthHolland Biomedical Press, Amsterdam, The Netherlands.

Telford, J., and J. Cosgrave. 2007.The international humanitarian system and the 2004 Indian Ocean earthquake and tsunami. Disasters 31(1):1-28.

The Consultative Group on Indonesia. 2005. Indonesia: preliminary damage and loss assessment. The December 26, 2004 Natural Disaster. Technical Report, Bappenas and the International Donor Community, Jakarta, Indonesia. [online] URL: http://www.unep.org/tsunami/reports/damage assessment. pdf

Tierney, K. 2007. From the margins to the mainstream? Disaster research at the crossroads. Annual Review of Sociology 33:503-535.
Umitsu, M., C. Tanavud, and B. Patanakanog. 2007. Effects of landforms on tsunami flow in the plains of Banda Aceh, Indonesia, and Nam Khem, Thailand. Marine Geology 242:141-153.

Weathers, F. W., B. T. Litz, D. S. Herman, J. A. Huska, and T. M. Keane. 1993. The PTSD checklist: reliability, validity, and diagnostic utility. Paper presented at the Annual Meeting of the International Society for Traumatic Stress Studies, San Antonio, Texas, USA. 